\title{
Genetic architecture of retinal and macular degenerative diseases: the promise and challenges of next-generation sequencing
}

\author{
Rinki Ratnapriya ${ }^{*}$ and Anand Swaroop*
}

\begin{abstract}
Inherited retinal degenerative diseases (RDDs) display wide variation in their mode of inheritance, underlying genetic defects, age of onset, and phenotypic severity. Molecular mechanisms have not been delineated for many retinal diseases, and treatment options are limited. In most instances, genotype-phenotype correlations have not been elucidated because of extensive clinical and genetic heterogeneity. Next-generation sequencing (NGS) methods, including exome, genome, transcriptome and epigenome sequencing, provide novel avenues towards achieving comprehensive understanding of the genetic architecture of RDDs. Whole-exome sequencing (WES) has already revealed several new RDD genes, whereas RNA-Seq and ChIP-Seq analyses are expected to uncover novel aspects of gene regulation and biological networks that are involved in retinal development, aging and disease. In this review, we focus on the genetic characterization of retinal and macular degeneration using NGS technology and discuss the basic framework for further investigations. We also examine the challenges of NGS application in clinical diagnosis and management.
\end{abstract}

\section{Genetics of retinal degenerative diseases}

The retina is our window to the outside world and is the site of capture, integration and processing of visual information. The vertebrate retina consists of a retinal pigment epithelium (RPE) monolayer, Müller glial cells, and six major types of neurons (Figure 1a) [1,2]. In mouse and human retinas, rods constitute over $95 \%$ of the photoreceptors and are responsible for night vision; whereas different cone sub-types (red, long wave-length (L); green,

\footnotetext{
* Correspondence: rinki.ratnapriya@nih.gov; swaroopa@nei.nih.gov Neurobiology-Neurodegeneration and Repair Laboratory, National Eye Institute, National Institutes of Health, Bethesda, MD 20892, USA
}

medium wave-length $(\mathrm{M})$; and blue, short wave-length (S)) are associated with daylight vision, color perception and high visual acuity [3,4]. The distribution of rod and cone photoreceptors is not uniform in the retina; for example, in humans, the central part of the retina (fovea) and a $6 \mathrm{~mm}^{2}$ cone-rich area around the fovea (macula) are responsible for high-resolution central vision (Figure 1b) [5]. Rhodopsin is the visual pigment in the rods, whereas the three kinds of cones in humans contain a distinct visual pigment (L-, $\mathrm{M}$ - and S-opsin in $\mathrm{L}, \mathrm{M}$, and S-cones, respectively) [4]. Development and homeostasis in the retina must be stringently controlled for normal vision [6].

The dysfunction or death of retinal photoreceptors is the primary cause of vision loss in the majority of retinal degenerative diseases (RDDs) [7,8], which are clinically and genetically heterogeneous. In general, loss of photoreceptors in the macular region is termed macular degeneration and results in central vision defects. By contrast, the loss of peripheral vision - for example, in retinitis pigmentosa (RP) - generally starts with rod dysfunction or death that is followed by cone degeneration. RDDs are associated with a diverse spectrum of phenotypes. Some, such as RP, congenital and early-onset retinal degeneration including Leber congenital amaurosis (LCA), and cone-rod dystrophies, are monogenic and non-syndromic. Some syndromic diseases, including Bardet-Biedl syndrome (BBS) and Usher syndrome, exhibit a highly penetrant retinal degeneration phenotype with multiple affected tissues and are also monogenic. Other RDDs, such as age-related macular degeneration (AMD), glaucoma, and diabetic retinopathy, are complex multifactorial entities.

Monogenic RDDs, by definition, are often caused by mutations in a single gene and have a Mendelian pattern of inheritance (dominant, recessive, or X-linked). Geneticlinkage studies in large pedigrees have led to the identification of almost 200 causative genes [9]. Genetic defects in monogenic RDDs are highly penetrant, with little influence of non-genetic factors; nevertheless, clinical severity has 


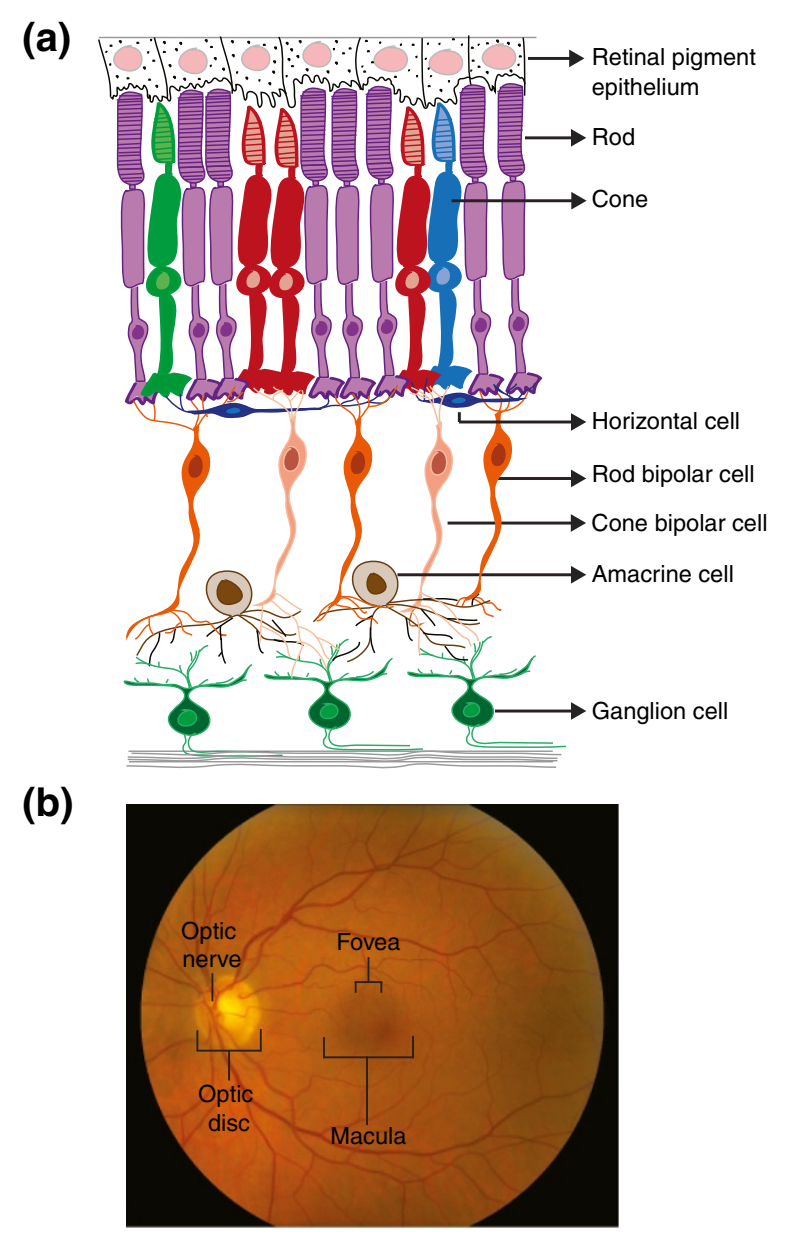

Figure 1 Structure of the retina. (a) Schematic organization of retinal circuits. The vertebrate retina consists of six major types of neurons - rod and cone photoreceptors, horizontal, bipolar, amacrine and ganglion cells. The rod and cone photoreceptors are specialized light-sensing neurons, which capture photons and transduce visual signals to the inner retina. The RPE serves as a barrier between the choroidal capillaries and the neural retina and is crucial for photoreceptor survival. Bipolar cells relay signals to the amacrine and ganglion cells through synapses in the inner plexiform layer. Ganglion cell axons project towards the optic nerve head and carry signals to the brain. (b) Ocular fundus photograph of a healthy retina showing retinal blood vessels, optic disc, macula (5 to $6 \mathrm{~mm}$ diameter), and fovea (central pit of the macula). Photograph provided by Dr Emily Chew (National Eye Institute, National Institutes of Health, Bethesda, MD).

often been difficult to correlate to genetic mutation because of variable penetrance, mutations in more than one gene, or modifier variants. The clinical manifestations in complex multifactorial RDDs result from the interplay among multiple susceptibility genes and epigenetic and/or environmental factors; therefore, conventional linkage and positional cloning methods have not been very effective in identifying the underlying genetic cause(s). Candidate gene and genome-wide association studies (GWAS) have been successful in identifying susceptibility loci for complex RDDs. A recent meta-analysis of GWAS discovered at least
19 genes and associated cellular pathways for AMD pathogenesis; these included the complement system $(\mathrm{CFH}$, $C 2 / C F B, C 3$ and $C F I)$, the high-density lipoprotein pathway (LIPC and CETP), the extracellular or collagen matrix pathway (TIMP3, COL8A1and COL1OA1) and the angiogenesis signaling pathway (VEGFA) [10]. Several loci have also been identified for primary open angle glaucoma [11-13] and diabetic retinopathy [14]. The associated alleles do not, however, specify causality, and further genetic and functional dissection of susceptibility loci will be crucial for understanding their roles in disease pathogenesis.

The discovery of new RDD genes helps in the elucidation of the molecular pathways that underlie retinal development and homeostasis, and in delineating the genetic underpinnings of the degenerative process. Several recent reviews have provided excellent synopses of the genetic and biological features of human RDDs [7,8,15-18]. We therefore focus on recent advances in next-generation sequencing (NGS) methods [19] (Boxes 1 and 2) that have provided an unprecedented opportunity for the unbiased discovery of genes and causal variants, and for the comprehensive dissection of the genetic architecture of RDDs. We also highlight the merits and limitations associated with different NGS methods, and present a framework for integrative analyses to elucidate a more complete, multidimensional view of genomic function in retinal health and diseases. Finally, we discuss the progress and challenges in the application of NGS approaches for diagnosis and management of RDDs.

\section{NGS approaches for gene identification in Mendelian RDDs}

Extensive genetic and clinical heterogeneity is observed in RDDs that have Mendelian inheritance. Although almost 200 genes have been identified, the genetic defects in many patients are still unknown. NGS offers a rapid, high-throughput and cost-effective approach to identify mutations underlying monogenic disorders.

\section{Whole-exome sequencing}

A majority of Mendelian diseases are caused by highly penetrant mutations that disrupt protein coding or splice site sequences. Conventional methods of gene identification involve linkage analysis followed by sequencing of candidate genes in the critical linked region. However, small pedigrees and simplex cases (Box 1) with uncertain inheritance patterns make it difficult to identify genetic defects using the positional-candidate strategy. Whole-exome sequencing (WES) involves the capture and sequencing of all coding exons ( 1 to $2 \%$ of the whole genome) (Box 1 ) and has become an ideal choice for Mendelian disease gene discovery with or without prior linkage information [20-24] (Figure 2). A majority of commercially available exome capture kits target with high-confidence a subset of genes annotated by the Consensus Coding Sequence (CCDS) project [25] and 


\section{Box 1. Glossary}

Next-generation sequencing (NGS): also known as massively parallel sequencing or high-throughput sequencing; these recent technologies allow parallel sequencing of multiple samples and produce millions of sequence reads concurrently, thereby reducing the sequencing costs and time considerably.

Mendelian disease: also called monogenic disease; results from single genetic defect(s) that are passed on to the next generation in a Mendelian inheritance pattern (dominant, recessive, or X-linked).

Complex disease: a multifactorial disease that does not exhibit a simple Mendelian inheritance pattern and is caused by complex interplay among genetic, epigenetic and environmental factors.

Simplex case: also known as sporadic cases; those in which only a single individual has a clinical diagnosis and no relatives are affected.

Whole-genome sequencing (WGS): sequencing of the complete DNA of an organism's genome. Whole-exome sequencing (WES): capture and sequencing of the coding exons of all genes, comprising roughly 1 to $2 \%$ of the genome.

Targeted re-sequencing: sequencing of a defined (targeted) region of the genome; helpful in identifying disease variant(s) when a linkage region has been established.

Transcriptome: the complete set of coding and non-coding transcripts (RNAs) expressed in a specific cell type, tissue or organism.

RNA-Seq: sequencing of transcriptome using NGS; RNA-Seq includes only the transcribed sequences of the genome.

RNA CaptureSeq: use of tiling arrays to capture and sequence selected portions of the transcriptome.

Chromatin immunoprecipitation (ChIP): a method for investigating the genomic DNA region(s) that are interacting with a protein in vivo, by capturing the DNA that is bound to a specific antibody.

ChIP-Seq: combines ChIP with NGS to generate a genome-wide map of DNA-binding proteins; can be used to identify genomewide epigenetic marks on histones.

cis-Regulatory element (CRE): DNA sequence in or near a gene (in cis) containing binding sites for transcription regulatory proteins that control the spatiotemporal expression of the target gene.

Single-end sequencing: sequencing of a DNA molecule only from one end; as NGS reads can be small, single-end sequencing might not be efficient in mapping low complexity and repetitive regions of the genome.

Paired-end sequencing: sequencing of a DNA molecule from both ends, resulting in a superior alignment across the genome. Mapping sequence assembly: mapping of NGS reads to a reference genome.

De novo assembly: a method of generating large assemblies of NGS reads in the absence of a reference genome.

Single nucleotide polymorphisms (SNPs): genetic variations that alter a single nucleotide in the genome.

Insertion-deletion variation (indel): any sequence change that leads to the addition or removal of one or more nucleotides compared to the reference genome.

eQTL analysis: analysis of genomic loci that have statistically significant correlation between genotype and gene expression levels, and thus regulate gene expression levels.

Copy number variation (CNV): a segment of DNA $(>1 \mathrm{~kb})$ that is present at a variable copy number compared to the reference genome, altering the diploid status at a particular locus.

Deleterious variant: a DNA change that lowers the fitness of the gene by altering the expression or function of the encoded protein or RNA and remains under the selection of various strengths.

Neutral variant: a variant that does not alter the function of a gene or confer any influence on the fitness of a gene.

Conserved variant (or conserved residue): a DNA nucleotide or amino acid residue that shares identity among closely

related species.

Private variant: a genetic variant that is confined to a single individual or a family.

Incidental or secondary findings: refers to the identification of any genetic finding that has health or reproductive relevance for the patient, but was not obtained as a part of the original goals of the study.

the RefSeq collection [26]. Ever since it was first described in 2009 as proof-of-concept for Freeman-Sheldon syndrome [21], several studies have successfully employed WES for identifying dozens of genes in inherited diseases. With regard to retinal phenotypes, it was first employed to study an Ashkenazi Jewish family, in which WES of three affected siblings revealed a mutation in a novel gene, $D H D D S$, as a cause of RP [27]. Table 1 provides a summary of published reports of novel retinal disease genes discovered by WES. 


\section{Box 2. Next-generation sequencing methods}

Next-generation sequencing: also known as massively parallel sequencing or high-throughput sequencing, this process enables the sequencing of a large number of DNA sequences in a single reaction; NGS has revolutionized the genomics field by producing fast, inexpensive and accurate sequencing data.

Platforms: several NGS platforms are commercially available, including Roche/454, Illumina/Solexa, ABI SOLiD, Life/APG, Helicos BioSciences and Pacific Biosciences; Illumina is a widely used platform because it provides large throughput at low cost.

Template preparation: starting material (genomic DNA, cDNA or immuno-precipitated DNA) is sheered to small-size fragments of 30 to 400 base pairs and ligated to a universal adapter. DNA can then be amplified using emulsion PCR or bridging amplification, followed by sequencing, or in the case of single molecule templates, sequenced directly.

Sequencing reaction: NGS chemistry methods (cyclic reversible termination, sequencing by ligation, pyrosequencing and real-time sequencing) vary among different platforms; sequencing by synthesis (SBS) is a commonly used approach that includes the use of DNA polymerase or DNA ligase for stepwise nucleotide addition.

Output: high throughput is a key feature of NGS protocols, with a single run producing several gigabases (Gb) of sequence data. Output varies among platforms; for example, Illumina HiSeq 2000 produces 95 to 600 Gb and SoLiD/ABI 5500 produces 90 to 300 Gb in a single run.

Assembly and mapping: once sequencing is accomplished, the initial analysis of base calling is performed by proprietary software on the sequencing platform, followed by aligning the data to a known reference genome if available or by de novo assembly; short read lengths can make mapping in the repetitive regions challenging.

Analysis: downstream analysis varies depending on the biological question;

DNA-Seq data are subjected to variant and CNV detection, whereas RNA-Seq data are used to characterize the transcriptome and ChIP-Seq; is used for large-scale analysis of chromatin features.

\section{Candidate exome capture}

In a slight variation of WES, candidate exome sequencing captures the selected coding regions that are relevant to a specific genetic trait. Consequently, the examination of a smaller genomic region allows better utilization of resources and the analysis of a larger group of patients. This approach has been useful for ciliopathies, where almost 2,500 genes that are implicated in ciliary function can serve as potential candidates [58]. Candidate exome capture of about 13,000 exons from 828 candidate genes recently identified mutations in the SDCCAG8 gene in patients with retinal-renal ciliopathies [56]. Mutations in a single gene can cause overlapping syndromic phenotypes, and so the candidate exome capture strategy helps in refining genotype-phenotype correlations.

\section{Targeted re-sequencing}

Mendelian traits have often been mapped using multigenerational families, narrowing the genomic search space for causal gene identification. Owing to the limited number of meiotic crossing-overs, however, linkage intervals can often span several megabases and include tens or hundreds of transcribed sequences. Intelligent guesses to select and sequence candidate genes can lead to laborintensive and expensive efforts that often provide limited data on the coding regions of annotated genes. NGS can now be used to capture and sequence large genomic regions of interest, expediting the discovery of causal genes (Table 1).

\section{Whole-genome sequencing}

WES, candidate exome capture and targeted re-sequencing can examine only a fraction of the genome and present additional challenges (Table 2). A role for variants beyond coding regions has occasionally been reported in Mendelian traits, including in vision disorders; for example, intronic mutations in RP1 [59] and OFD1 [53] are implicated as causes of RP, and CSPG2 variants may cause congenital vitreoretinopathies [60]. The inability of WES to assess the impact of non-coding, conserved or regulatory regions, and other long-range genomic alterations has encouraged researchers to move towards whole-genome sequencing (WGS), which is becoming more cost-effective. Nevertheless, progress has been slow because of the technological limitations associated with the analysis and handling of large datasets.

\section{RNA-Seq or transcriptome sequencing}

The transcriptome represents a collection of all transcribed sequences (RNAs), both protein-coding and noncoding, in a cell type or particular tissue and at a specific stage of development or age. While microarray technology and methods for serial analysis of gene expression (SAGE) have been valuable, transcriptome profiling using NGS technology (RNA-Seq) is becoming popular because of its ability to survey the transcriptome in a high-throughput and quantitative manner and at low cost [61]. In addition, RNA-Seq has proven useful for annotating protein-coding genes, discovering novel alternatively spliced transcripts 


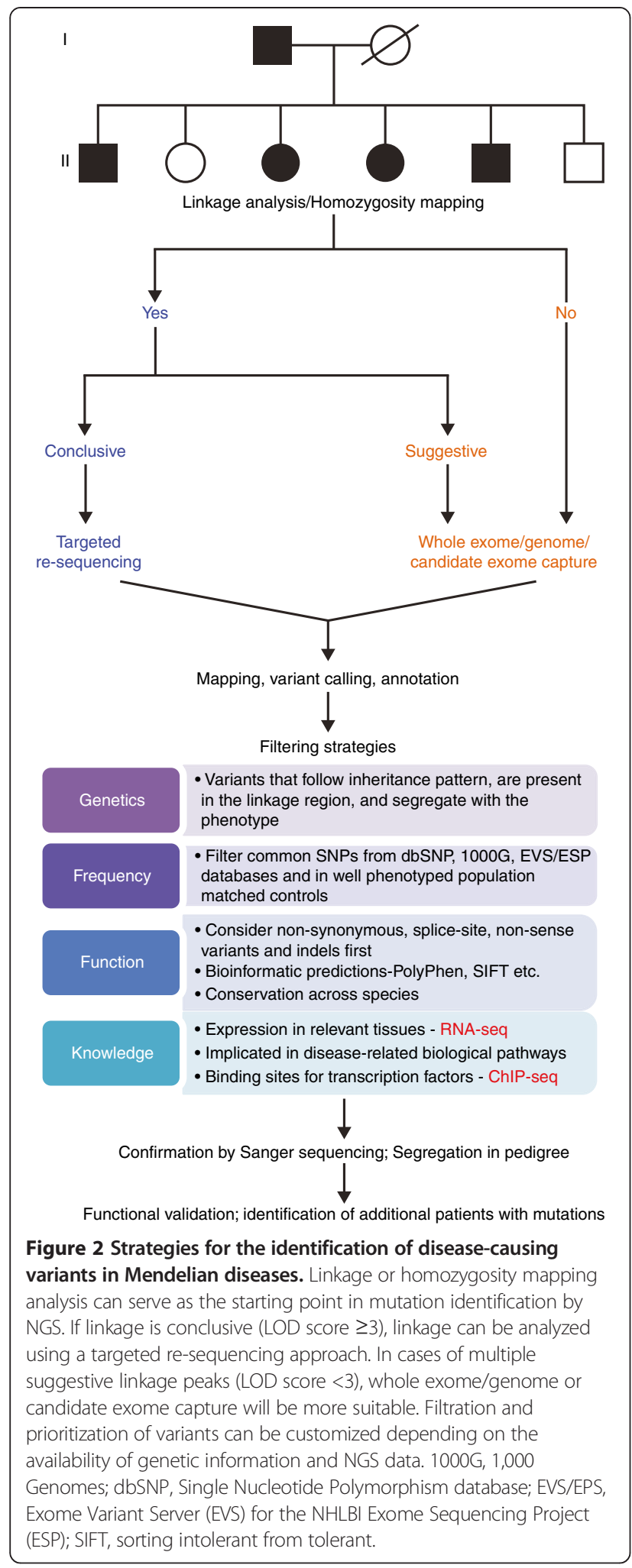

and non-coding RNAs (ncRNAs), single nucleotide polymorphism (SNP) profiling, and the detection of gene fusions or rearrangements [62]. DNA-Seq approaches generate a large number of variants and often secondary filtering is required to prioritize the candidate disease genes. Tissue-specific expression profiles therefore offer a valuable first-level screen to identify relevant diseasecausing variants (Figure 2).

\section{Profiling of alternative transcripts}

In humans, a majority of genes $(>90 \%)$ undergo alternative splicing to generate tissue-specific and functionally diverse protein isoforms [63]. The role of novel transcripts in diverse pathways and disease causation is slowly being recognized [64,65]. Retina-specific isoforms of $R P G R$ and $B B S 3$ have been implicated in X-linked RP and BBS, respectively [66,67]. In addition, mutations in the spliceosome-component genes (PRPF31, PRPF3, and PRPF8) are associated with RP [68]. Thus, retina-specific RNA or transcriptome profiling provides an excellent opportunity to identify novel functionally relevant transcripts. As novel transcripts may be present at low-copy number, RNA CaptureSeq (Box 1) can provide an alternative approach for enrichment [69].

\section{Non-coding RNA}

ncRNAs appear to play prominent and diverse roles in normal development, physiology, and disease. Several specific microRNAs (miRNAs) are expressed in the retina (miR-96, miR-182, and miR-183) [70,71] and RPE (miR-204/211) [72]. Long antisense (non-coding) transcripts have been associated with eight transcription factors that are involved in eye development [73], and two ncRNAs, TUG1 [74] and Six3OS [75], have been linked to retinal differentiation. Inactivation of DICER1, an RNase III endonuclease that is essential for the production and function of mature miRNAs, has been implicated in retinal degeneration [76], and Alu RNA toxicity has been suggested to a play a role in AMD [77]. Thus, further exploration of ncRNAs seems essential, and RNA-Seq offers a starting point for the identification of novel ncRNAs in development and disease.

\section{SNP profiling}

Genetic variations within the transcribed (coding or noncoding) regions of the genome can alter the expression or function of the encoded sequence. Therefore, RNA-Seq can provide profiles of genetic variants in both the quasicomplete set of transcribed genes (mRNAs) and ncRNAs in a cost-effective manner and without the need for target-probe hybridization, a necessary but inefficient step in capture-based methods. However, RNA-Seq should be applied with caution, as it is possible to miss variants that result in the loss of a gene product.

\section{ChIP-Seq-based approaches}

The genomic location and function of regulatory elements contributes significantly to the development of human 
Table 1 List of novel genes identified in retinal and macular degeneration using next-generation sequencing approaches

\begin{tabular}{|c|c|c|c|c|c|}
\hline Method & Disease & Gene symbol & Inheritance & Aberration type & Reference(s) \\
\hline \multirow[t]{22}{*}{ Whole-exome sequencing } & \multirow[t]{7}{*}{ Retinitis pigmentosa (RP) } & DHDDS & Recessive & Missense & {$[27]$} \\
\hline & & MAK & Recessive & Alu insertion & {$[28]$} \\
\hline & & GNPTG & Recessive & 6-bp deletion & {$[29]$} \\
\hline & & EMC1 & Recessive & Missense & {$[30]$} \\
\hline & & GPR125 & Recessive & Frame-shift, splice-site & {$[30]$} \\
\hline & & KIAA1549 & Recessive & Frame-shift & {$[30]$} \\
\hline & & $A R L 2 B P$ & Recessive & Splice-acceptor, missense & {$[31]$} \\
\hline & \multirow[t]{3}{*}{ Leber congenital amaurosis (LCA) } & NMNAT1 & Recessive & Missense and truncation & {$[32-35]$} \\
\hline & & KCNJ13 & Recessive & Truncation & {$[36]$} \\
\hline & & DTHD1 & Recessive & Missense & {$[30]$} \\
\hline & \multirow[t]{2}{*}{ Congenital stationary night blindness (CSNB) } & LRIT3 & Recessive & Missense and truncation & {$[37]$} \\
\hline & & GPR179 & Recessive & Missense and truncation & {$[38]$} \\
\hline & Ciliopathy with skeleton abnormality & WDR19 & Recessive & Missense and truncation & {$[39]$} \\
\hline & High myopia & ZNF644 & Dominant & Missense & {$[40]$} \\
\hline & Bardet-Biedl syndrome (BBS) & LZTFL1 & Recessive & Truncation & {$[41]$} \\
\hline & Nephronophthisis with retinal degeneration & $\begin{array}{l}\text { ZNF423 and } \\
\text { CEP164 }\end{array}$ & Recessive & $\begin{array}{l}\text { Missense, truncation, } \\
\text { loss of stop codon }\end{array}$ & {$[42]$} \\
\hline & Usher syndrome & HARS & Recessive & Missense & {$[43]$} \\
\hline & Benign fleck retina & PLA2G5 & Recessive & Missense and truncation & {$[44]$} \\
\hline & \multirow[t]{3}{*}{ Cone-rod dystrophy } & $R A B 28$ & Recessive & Truncation & {$[45]$} \\
\hline & & ACBD5 & Recessive & Frame-shift & {$[30]$} \\
\hline & & C21orf2 & Recessive & Frame-shift & {$[30]$} \\
\hline & Knobloch syndrome and retinal dystrophy & ADAMTS18 & Recessive & Missense & {$[46,47]$} \\
\hline \multirow[t]{8}{*}{ Targeted sequencing } & RP, cone-rod dystrophy & C8orf37 & Recessive & Truncation & {$[48]$} \\
\hline & \multirow[t]{2}{*}{ AMD } & $\mathrm{CFH}$ & Dominant & Missense & {$[49]$} \\
\hline & & $\mathrm{CFI}$ & Dominant & Missense & {$[50]$} \\
\hline & Usher syndrome & ABHD12 & Recessive & Truncation & {$[51]$} \\
\hline & CSNB & GPR179 & Recessive & Large insertion & {$[52]$} \\
\hline & $X$-linked RP & OFD1 & X-linked & Intronic mutation & {$[53]$} \\
\hline & Jobert syndrome & TMEM237 & Recessive & Truncation & {$[54]$} \\
\hline & Familial exudative vitreoretinopathy & TSPAN12 & Dominant & Missense & {$[55]$} \\
\hline Candidate exome capture & Retinal- renal ciliopathy & SDCCAG8 & Recessive & Truncation mutations & {$[56]$} \\
\hline cis-Regulatory mapping & $\mathrm{RP}$ & MAK & Recessive & Truncation mutation & {$[57]$} \\
\hline
\end{tabular}

All of the diseases listed here, except AMD, are monogenic. AMD is a multifactorial and complex disease.

diseases. Chromatin immunoprecipitation followed by NGS (ChIP-Seq) can be used to profile cis-regulatory elements (CREs) (Box 1), which include transcription factor binding sites clustered within promoters, enhancers and silencers [78]. ChIP-Seq has been employed to generate genomewide maps of CREs for two key photoreceptor-specific transcription factors, CRX [79] and NRL [80]. In addition, these data have permitted the prioritization of diseaseassociated genes or variants for further study. Not surprisingly, several $C R X$ and $N R L$ target genes are associated with RDDs [79,80], and recently, $C R X$ ChIP-Seq data were used to filter the candidates to identify mutations in MAK (encoding a regulator of ciliary length) as a cause of autosomal recessive RP [57].

ChIP-Seq can also be employed for genome-wide profiling of epigenetic modifications, such as DNA methylation and covalent modifications of histones [81]. Epigenetic variations can influence gene expression and developmental programming $[82,83]$. Evidence suggests the involvement of epigenetic mechanism in RDDs; but such modifications are more likely to be associated with complex disorders, such as AMD [84], glaucoma and diabetic retinopathy. 
Table 2 A comparison of next-generation sequencing methodologies

\begin{tabular}{|c|c|c|c|}
\hline Method & Advantages & Limitations & Applications \\
\hline $\begin{array}{l}\text { Whole-exome } \\
\text { sequencing or } \\
\text { candidate } \\
\text { exome capture }\end{array}$ & $\begin{array}{l}\text { Customized, economical compared } \\
\text { to WGS, manageable data size }\end{array}$ & $\begin{array}{l}\text { Captures genetic variants only in the coding } \\
\text { regions of the genome; inefficient hybridization } \\
\text { step; high DNA input; susceptible to capture bias }\end{array}$ & $\begin{array}{l}\text { SNP and indel discovery in coding exons; } \\
\text { suitable for the identification of causal } \\
\text { genes in high-penetrance Mendelian } \\
\text { diseases }\end{array}$ \\
\hline $\begin{array}{l}\text { Targeted } \\
\text { re-sequencing }\end{array}$ & $\begin{array}{l}\text { Customized, economical compared } \\
\text { to WGS }\end{array}$ & $\begin{array}{l}\text { Genetic variant discovery is limited by array } \\
\text { design; high DNA input; inefficient hybridization } \\
\text { step; captures only a small proportion of the genome }\end{array}$ & $\begin{array}{l}\text { SNP and indel discovery; suitable for } \\
\text { sequencing linkage intervals and genomic } \\
\text { regions at or around associated signals }\end{array}$ \\
\hline $\begin{array}{l}\text { Whole- } \\
\text { genome } \\
\text { sequencing }\end{array}$ & $\begin{array}{l}\text { Uncovers genome-wide coding } \\
\text { and non-coding variants, no } \\
\text { capture bias }\end{array}$ & $\begin{array}{l}\text { Expensive; very large dataset; analysis methods are } \\
\text { still evolving }\end{array}$ & $\begin{array}{l}\text { Genome-wide SNP, indel and CNV } \\
\text { discovery; suitable for rare variant discovery } \\
\text { in Mendelian, complex or sporadic traits }\end{array}$ \\
\hline Exome-chip & $\begin{array}{l}\text { Cost-effective method for } \\
\text { evaluating known rare variants } \\
\text { (MAF of } 1 \text { to } 5 \% \text { ) }\end{array}$ & $\begin{array}{l}\text { Does not identify novel variants; limited to } \\
\text { coding region; limited representation of intronic } \\
\text { and regulatory variants }\end{array}$ & $\begin{array}{l}\text { Genome-wide association analysis } \\
\text { with rare variants }\end{array}$ \\
\hline RNA-Seq & $\begin{array}{l}\text { Array-independent profiling of the } \\
\text { transcriptome }\end{array}$ & $\begin{array}{l}\text { High coverage required for the identification of } \\
\text { low-copy transcripts; not applicable for the } \\
\text { identification of variants that cause loss of protein; } \\
\text { limited by tissue- or cell-type availability }\end{array}$ & $\begin{array}{l}\text { Genome-wide expression profiling; } \\
\text { alternative transcript identification; } \\
\text { non-coding RNA detection; } \\
\text { SNP profiling; eQTL analysis }\end{array}$ \\
\hline ChIP-Seq & $\begin{array}{l}\text { Genome-wide profiling of epigenetic } \\
\text { marks (DNA methylation and histone } \\
\text { modifications) and cis-regulatory } \\
\text { elements }\end{array}$ & $\begin{array}{l}\text { Dependent on the quality of antibody; requires } \\
\text { high input; analysis methods still evolving; high } \\
\text { coverage needed for accurate profiling }\end{array}$ & $\begin{array}{l}\text { DNA methylation; histone modifications; } \\
\text { tissue-specific enhancer profiling }\end{array}$ \\
\hline
\end{tabular}

Epigenetic profiling of retina, RPE and other eye tissues or cells, in combination with gene profiling, should provide valuable insights into disease mechanisms. The Encyclopedia of DNA Elements (ENCODE) project has systematically integrated gene expression data with information on regulatory elements, transcription factor binding, and epigenetic modifications for as much as $80 \%$ of the genome [85]. Expression profiles and other data relevant to retinal and macular diseases have not, however, been incorporated as yet.

\section{NGS approaches for complex traits}

The identification of the genetic susceptibility variants underlying complex multifactorial disorders requires extensive efforts including large patient cohorts and cumbersome analytical tools. GWAS have been successful in uncovering associated loci for numerous diseases, but such studies only examine common (tagging) variants in populations and additional investigations are necessary to identify causality. In this section, we provide an overview of the possible applications of NGS, with an emphasis on the study design for complex diseases.

\section{GWAS and meta-analysis}

GWAS have begun to unravel the genetic architecture of complex traits. Hundreds of susceptibility loci associated with multifactorial diseases have now been discovered [86]. AMD provided the first example of GWAS success with the identification of $C F H$ susceptibility loci [87]. Multiple GWAS and large-scale meta-analysis studies have to date revealed as many as 19 AMD susceptibility loci $[10,88]$. However, the associated variants are not causal and do not explain a substantial fraction of genetic heritability. Rare and structural variants at these associated susceptibility loci might help to explain the causality and missing heritability [89]. NGS approaches have made the identification of rare alleles feasible and have ushered in a new era for a second-generation of association studies in complex diseases (Figure 3).

\section{Rare variant identification}

The hypothesis that rare variants influencing a complex trait should co-localize with associated common alleles has accelerated targeted re-sequencing of the GWAS loci [90]. Such studies have led to the identification of rare coding variants, R1210C in CFH [49] and G119R in CFI [12], that are associated with AMD. WES studies are also being performed to test the association of rare coding variants with a complex phenotype [91,92]. However, such studies require a large sample size to achieve the statistical power necessary to detect a significant association that can then justify multiple testing. In the absence of such a dataset, extreme phenotype study design, in which samples from both ends of the phenotype distribution are analyzed, can serve as a suitable alternative (Figure 3) [93]. In addition, inherited macular dystrophies share common clinical characteristics with AMD, and occasionally genes identified in heritable forms, such as TIMP3 [94] and $A B C A 4$ [95], have been associated with AMD [88,96]. Thus, WES and WGS in families with macular dystrophies (and occasionally in available AMD families) can uncover rare variants that might contribute to disease pathophysiology. 


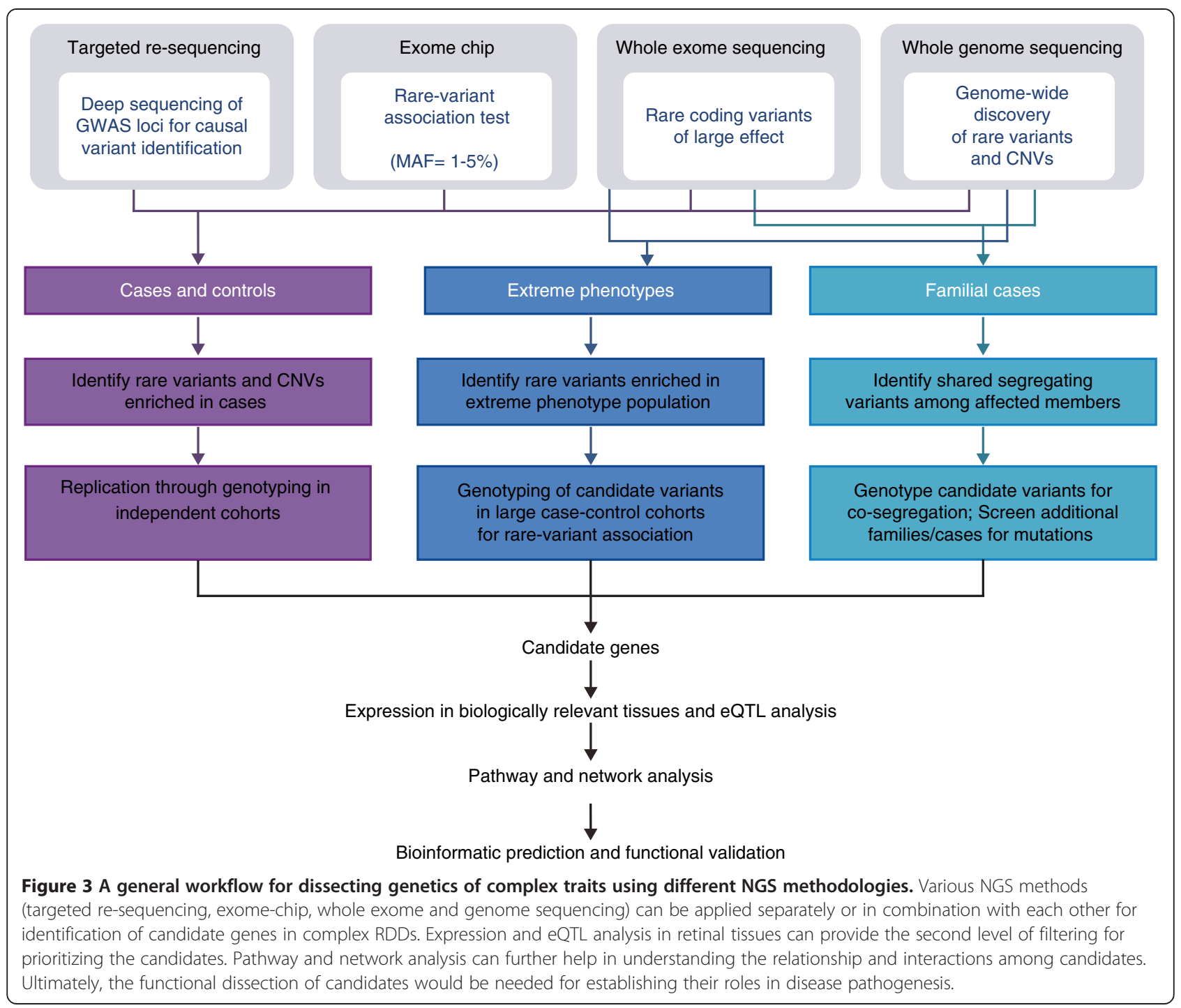

\section{Copy number variations}

Large DNA stretches (>1 kb) that exhibit variable copy number when compared to the reference genome contribute significantly to population dynamics and evolution. Comparative genomic hybridization (CGH) arrays and SNP arrays have been commonly used to detect copy number variations (CNVs) that are implicated in neurodevelopmental (autism, schizophrenia, and intellectual disability) and immune-related diseases (Crohn's disease, psoriasis, HIV/ AIDS, rheumatoid arthritis, and type I diabetes) [97]. The role of CNVs is under investigation in AMD [98-100]. An 84-kb deletion spanning CFHR1 and CFHR3 has been associated with protection against the development of AMD [101-103]. A recent GWAS has identified CNVs at NPHP1 and EFEMP1 as potential candidates for AMD association [100]. CNVs in additional genes, such as CCR3, CFH, CX3CR1, ERCC6, HTRA1, VEGF, GSTM1, and GSTT1, have also been associated with AMD [104]. Nevertheless, a complete spectrum of CNVs in complex diseases (including AMD) has not been realized yet because of the limited resolution of current methods. NGS-based CNV detection utilizes high-coverage WGS data for unbiased detection of $\mathrm{CNVs}$ at much higher resolution than has been available to date, providing information about CNV breakpoints and the location of copy number gains [105,106]. Nevertheless, methodologies for CNV detection using NGS lack welldefined workflows, protocols, and quality-control measures, imposing substantial computational and bioinformatic challenges [107]. In addition, databases for human structural variation are limited and contain inadequate information on most breakpoints. A validated pipeline for structural variation analysis using NGS data is highly desirable for utilizing the full potential of CNVs for complex trait analysis. 


\section{Exome-chip}

A common-variant-based GWAS approach has not explained the complete genetic variance observed in complex traits. Missing heritability might be explained by rare to low frequency variants (minor allele frequency (MAF) of 1 to 5\%) [90,108,109]. NGS studies, such as the 1,000 Genomes Project [110] and the NHLBI Exome Sequencing Project [111], have identified a large number of such variants, leading to a second-generation genotyping array for testing the association of rare variants in complex traits [112]. Ideally, all common GWAS variants that are associated with distinct phenotypes can be included in such exome-chips. Although any regulatory or novel rare variant is not identified by this approach in RDDs, exome chips offer an economical and rapid platform that can be used to test the hypothesis that certain rare variants are causal alleles in common diseases. Such studies are currently in progress as part of a large AMD consortium and should identify novel variants and genes in the near future.

\section{Expression quantitative trait loci analysis}

A vast majority of disease-associated SNPs identified in GWAS are reportedly located in non-coding regions of the genome, and their functional role in causing the disease is generally not understood. Arguably, such variants might regulate gene expression and act as expression quantitative trait loci (eQTL) [113]. Combined analysis of genotyping with RNA-Seq data provides a unique opportunity to correlate genetic variations and expression level at disease-associated loci [114]. Expression profiling is more relevant, however, when implemented in disease-affected tissues or cell types. Although little has been reported on the importance of eQTLs in RDDs, the integration of data on modifier and susceptibility variants with the NGS expression data would facilitate the elucidation of complex regulatory networks that can provide insights into novel intervention strategies.

\section{Making sense of the vast amount of NGS data for disease gene identification}

The identification of relevant candidate disease-causing variants from NGS data requires filtering strategies that depend on multiple factors, such as the availability of wellphenotyped patient cohorts, knowledge of the mode of inheritance, and large sample sizes. Computational tools that can predict the impact of a variant on protein function can assist in segregating the deleterious variants from neutral ones [115]. A general guideline for candidate variant identification is provided for Mendelian (Figure 2) and complex RDDs (Figure 3), but each biological question might require a unique approach. For example, homozygosity and linkage data can complement WES or targeted sequencing in Mendelian RDDs [30,31,45-47]. Similarly, the integration of GWAS data with rare variant, eQTL or pathway-based analyses can yield meaningful results for complex traits such as AMD. Ultimately, validation of genetic causality would require additional investigations using in vitro assays and/or model organisms.

\section{NGS in diagnostics and disease management for RDDs}

Over 200 genes have been implicated in RDDs, offering an opportunity to clarify etiology, provide prognosis, and calculate associated risk(s). Nevertheless, molecular diagnosis and counseling are complicated by genetic heterogeneity and extensive phenotypic variability. Mutations in the same gene can cause different phenotypes and similar clinical findings can result from mutations in different genes. For example, $R P G R$ and $R P 2$ are primary causative genes in X-linked RP, but recent studies have reported the prevalence of $R P 2$ and $R P G R$ mutations even in simplex retinal degeneration in males [116] and in pedigrees with 'apparent' autosomal dominant inheritance of RP [117]. Thus, the boundaries of distinct clinical entities can be blurred, demanding more comprehensive methods of molecular evaluation [118].

Customized arrays have been developed for screening patients with RP $[119,120]$ and other retinal dystrophies $[121,122]$. The National Eye Institute has established the National Ophthalmic Disease Genotyping and Phenotyping Network (eyeGENE ${ }^{\circledast}$ ), which offers molecular diagnosis as a service [123]. The eyeGENE ${ }^{\bullet}$ network currently includes Clinical Laboratory Improvement Amendments (CLIA)-certified diagnostic laboratory partners; over 270 registered clinical organizations with 500 registered users from around the United States and Canada have analyzed over 4,400 samples. eyeGENE ${ }^{\oplus}$ is also working towards setting up high-throughput genotyping and sequencing technologies for improved clinical sequencing. These efforts, however, need continuous validation of reliability, robustness and reproducibility of the technology being employed. Implementation of NGS hardware requires substantial in-house infrastructure and a standardized guideline for NGS protocols. Issues related to the ownership and confidentiality of genomic data and the handling of incidental or secondary findings (Box 1) must also be addressed before NGS technology moves into routine clinical practice.

\section{Understanding the biology of disease}

The extreme phenotypic variability in RDDs can be attributed to allelic heterogeneity, modifier loci, and epigenetic and environmental factors, or a combination of these. A modifier gene is predicted to alter the phenotypic outcome of a given genotype by interacting with the primary disease gene or by functioning in the same or a related biological pathway, affecting penetrance, expressivity 
and pleiotropy [124,125]. A few examples are warranted. Digenic inheritance has been reported for mutations in $R O M 1$ and peripherin/RDS resulting in RP [126] and for ROM1 and $A B C A 4$ mutations in macular dystrophy [127]. CNOT3 can modify the phenotype of a PRPF31 mutation in RP [128]. The potential involvement of mutations in more than one causative gene has also been described in LCA [129]. Phenotypic differences in ciliopathies are also attributed to modifiers [130,131]. For example, a common allele in RPGRIP1L, Ala229Thr, is reported to be a modifier of retinal degeneration in ciliopathy patients [132]. AHI1 seems to act as a modifier of CEP290 [133] and NPHP1 [134], and PDZD7 can modify the phenotype in Usher syndrome patients who have a homozygous USH2A mutation [135]. The search for modifiers has, however, been limited because of their non-Mendelian segregation and restricted exploration within known RDD genes, and because of the abundant normal genetic variations in humans. NGS approaches offer an expanded platform for genome-wide evaluation of modifier variants that would permit a better understanding of phenotypic variability and progression in RDDs.

Mouse models have provided valuable insights into RDD pathogenesis, but complex interactions among retinopathy proteins and additional variants can exacerbate or ameliorate the disease phenotypes. For example, mice that had a combination of Cep290 and Mkks disease alleles had better sensory functions than those with either mutation alone [136]. The development of therapeutic strategies would therefore require a comprehensive understanding of RDD gene interaction networks and cellular pathways. NGS technology should expedite the integration of genetic variants in relevant RDDs and modifier genes with retinal transcriptome and epigenetic profiles.

\section{Conclusions, challenges and future prospects}

It is an exciting time in the genetic analysis of RDDs as NGS has led to unprecedented access to various genomewide datasets. NGS has proven successful in identifying the genetic cause of monogenic RDDs in many patients and families and offers great promise for the genetic dissection of complex RDDs. With the generation and analysis of NGS data becoming more accessible and affordable, a comprehensive catalog of variants for most (if not all) vision-related traits seems a viable prospect. Whole-transcriptome and epigenome analysis in retinal tissues would greatly facilitate the elucidation of important pathways or networks underlying development and disease. In this review, we have highlighted the challenges and the opportunities in applying NGS for gene discovery and clinical diagnosis of RDDs. A major goal lies ahead in developing a unified framework for identifying all diseaserelevant variants and genes. Methods for downstream bioinformatic analyses are still evolving and represent a major bottleneck in NGS applications. There is significant room for improvement in mapping and variant-calling methods, especially for small insertions or deletions and CNVs. Better tools are required for combining information from across studies that have used different sequencing platforms or even distinct methods of data analysis. As each kind of NGS data has its own merits, integrated and multidimensional analyses of biological systems with relevant clinical information records would be valuable for intervention and personalized medicine.

\section{Abbreviations}

AMD: Age-related macular degeneration; BBS: Bardet-Biedl syndrome; ChIP: Chromatin immunoprecipitation; CNV: Copy number variation; CRE: cis-regulatory element; eQTL: Expression quantitative trait loci; GWAS: Genome-wide association studies; L: Long wave-length; LCA: Leber congenital amaurosis; M: Medium wave-length; MAF: Minor allele frequency; miRNA: microRNA; ncRNA: Non-coding RNAs; NGS: Next-generation sequencing; RDD: Retinal degenerative diseases; RP: Retinitis pigmentosa; RPE: Retinal pigment epithelium; S: Short wave-length; SNP: Single nucleotide polymorphism; WES: Whole-exome sequencing; WGS: Whole-genome sequencing.

\section{Competing interests}

The authors declare that they have no competing interests.

\section{Acknowledgements}

We thank Dr Emily Chew (National Eye Institute, National Institutes of Health, Bethesda, MD) for providing the fundus photograph of the human retina. This work is supported by the Intramural Research Program of the National Eye Institute.

\section{Published: 11 October 2013}

\section{References}

1. Dowling JE: The Retina: an Approachable Part of the Brain. Cambridge, MA: Belknap Press; 1987.

2. Masland RH: The fundamental plan of the retina. Nat Neurosci 2001, 4:877-886

3. Lamb TD, Collin SP, Pugh EN Jr: Evolution of the vertebrate eye: opsins, photoreceptors, retina and eye cup. Nat Rev Neurosci 2007, 8:960-976.

4. Nathans J, Thomas D, Hogness DS: Molecular genetics of human color vision: the genes encoding blue, green, and red pigments. Science 1986, 232:193-202.

5. Curcio CA, Sloan KR, Kalina RE, Hendrickson AE: Human photoreceptor topography. J Comp Neurol 1990, 292:497-523.

6. Swaroop A, Kim D, Forrest D: Transcriptional regulation of photoreceptor development and homeostasis in the mammalian retina. Nat Rev Neurosci 2010, 11:563-576.

7. Bramall AN, Wright AF, Jacobson SG, McInnes RR: The genomic, biochemical, and cellular responses of the retina in inherited photoreceptor degenerations and prospects for the treatment of these disorders. Annu Rev Neurosci 2010, 33:441-472.

8. Wright AF, Chakarova CF, Abd El-Aziz MM, Bhattacharya SS: Photoreceptor degeneration: genetic and mechanistic dissection of a complex trait. Nat Rev Genet 2010, 11:273-284.

9. RetNet. [https://sph.uth.edu/retnet/]

10. Fritsche LG, Chen W, Schu M, Yaspan BL, Yu Y, Thorleifsson G, Zack DJ, Arakawa S, Cipriani V, Ripke S, lgo RP Jr, Buitendijk GH, Sim X, Weeks DE, Guymer RH, Merriam JE, Francis PJ, Hannum G, Agarwal A, Armbrecht AM, Audo I, Aung T, Barile GR, Benchaboune M, Bird AC, Bishop PN, Branham KE, Brooks M, Brucker AJ, Cade WH, et al: Seven new loci associated with age-related macular degeneration. Nat Genet 2013, 45:433-439.

11. Thorleifsson G, Walters GB, Hewitt AW, Masson G, Helgason A, DeWan A, Sigurdsson A, Jonasdottir A, Gudjonsson SA, Magnusson KP, Stefansson H, Lam DS, Tam PO, Gudmundsdottir GJ, Southgate L, Burdon KP, Gottfredsdottir MS, Aldred MA, Mitchell P, St Clair D, Collier DA, Tang N, Sveinsson O, Macgregor S, Martin NG, Cree AJ, Gibson J, Macleod A, Jacob A, Ennis S, et al: Common variants near CAV1 and CAV2 are associated with primary open-angle glaucoma. Nat Genet 2010, 42:906-909. 
12. van Koolwijk LM, Ramdas WD, Ikram MK, Jansonius NM, Pasutto F, Hysi PG, Macgregor S, Janssen SF, Hewitt AW, Viswanathan AC, ten Brink JB, Hosseini SM Amin N, Despriet DD, Willemse-Assink JJ, Kramer R, Rivadeneira F, Struchalin M, Aulchenko YS, Weisschuh N, Zenkel M, Mardin CY, Gramer E, Welge-Lüssen U, Montgomery GW, Carbonaro F, Young TL, DCCT/EDIC Research Group, Bellenguez C, McGuffin P, et al: Common genetic determinants of intraocular pressure and primary open-angle glaucoma. PLOS Genet 2012, 8:e1002611.

13. Wiggs JL, Yaspan BL, Hauser MA, Kang JH, Allingham RR, Olson LM, Abdrabou W, Fan BJ, Wang DY, Brodeur W, Budenz DL, Caprioli J, Crenshaw A, Crooks K, Delbono E, Doheny KF, Friedman DS, Gaasterland D, Gaasterland T, Laurie C, Lee RK, Lichter PR, Loomis S, Liu Y, Medeiros FA, McCarty C, Mirel D, Moroi SE, Musch DC, Realini A, et al: Common variants at 9p21 and 8q22 are associated with increased susceptibility to optic nerve degeneration in glaucoma. PLOS Genet 2012, 8:e1002654

14. Grassi MA, Tikhomirov A, Ramalingam S, Below JE, Cox NJ, Nicolae DL: Genome-wide meta-analysis for severe diabetic retinopathy. Hum Mol Genet 2011, 20:2472-2481.

15. Priya RR, Chew EY, Swaroop A: Genetic studies of age-related macular degeneration: lessons, challenges, and opportunities for disease management. Ophthalmology 2012, 119:2526-2536.

16. Swaroop A, Chew EY, Rickman CB, Abecasis GR: Unraveling a multifactorial lateonset disease: from genetic susceptibility to disease mechanisms for agerelated macular degeneration. Annu Rev Genomics Hum Genet 2009, 10:19-43.

17. Pacione LR, Szego MJ, Ikeda S, Nishina PM, Mclnnes RR: Progress toward understanding the genetic and biochemical mechanisms of inherited photoreceptor degenerations. Annu Rev Neurosci 2003, 26:657-700.

18. Berger W, Kloeckener-Gruissem B, Neidhardt J: The molecular basis of human retinal and vitreoretinal diseases. Prog Retin Eye Res 2010, 29:335-375.

19. Metzker ML: Sequencing technologies - the next generation. Nat Rev Genet 2010, 11:31-46.

20. Bamshad MJ, Ng SB, Bigham AW, Tabor HK, Emond MJ, Nickerson DA, Shendure J: Exome sequencing as a tool for Mendelian disease gene discovery. Nat Rev Genet 2011, 12:745-755.

21. Ng SB, Turner EH, Robertson PD, Flygare SD, Bigham AW, Lee C, Shaffer T, Wong M, Bhattacharjee A, Eichler EE, Bamshad M, Nickerson DA, Shendure J: Targeted capture and massively parallel sequencing of 12 human exomes. Nature 2009, 461:272-276.

22. Choi M, Scholl UI, Ji W, Liu T, Tikhonova IR, Zumbo P, Nayir A, Bakkaloglu A, Ozen S, Sanjad S, Nelson-Williams C, Farhi A, Mane S, Lifton RP: Genetic diagnosis by whole exome capture and massively parallel DNA sequencing. Proc Natl Acad Sci U S A 2009, 106:19096-19101.

23. Gnirke A, Melnikov A, Maguire J, Rogov P, LeProust EM, Brockman W, Fennell T, Giannoukos G, Fisher S, Russ C, Gabriel S, Jaffe DB, Lander ES, Nusbaum C: Solution hybrid selection with ultra-long oligonucleotides for massively parallel targeted sequencing. Nat Biotechnol 2009, 27:182-189.

24. Priya RR, Rajasimha HK, Brooks MJ, Swaroop A: Exome sequencing: capture and sequencing of all human coding regions for disease gene discovery. Methods Mol Biol 2012, 884:335-351.

25. CCDS database. [http://www.ncbi.n/m.nih.gov/CCDS/CcdsBrowse.cgi].

26. RefSeq. [http://www.ncbi.nlm.nih.gov/refseq/].

27. Zuchner S, Dallman J, Wen R, Beecham G, Naj A, Faroog A, Kohli MA Whitehead PL, Hulme W, Konidari I, Edwards YJ, Cai G, Peter I, Seo D, Buxbaum JD, Haines JL, Blanton S, Young J, Alfonso E, Vance JM, Lam BL, Peričak-Vance MA: Whole-exome sequencing links a variant in DHDDS to retinitis pigmentosa. Am J Hum Genet 2011, 88:201-206.

28. Tucker BA, Scheetz TE, Mullins RF, DeLuca AP, Hoffmann JM, Johnston RM, Jacobson SG, Sheffield VC, Stone EM: Exome sequencing and analysis of induced pluripotent stem cells identify the cilia-related gene male germ cell-associated kinase (MAK) as a cause of retinitis pigmentosa. Proc Nat Acad Sci U S A 2011, 108:E569-E576.

29. Schrader KA, Heravi-Moussavi A, Waters PJ, Senz J, Whelan J, Ha G, Eydoux P, Nielsen T, Gallagher B, Oloumi A, Boyd N, Fernandez BA, Young TL, Jones SJ, Hirst M, Shah SP, Marra MA, Green J, Huntsman DG: Using next-generation sequencing for the diagnosis of rare disorders: a family with retinitis pigmentosa and skeletal abnormalities. J Patho/ 2011, 225:12-18

30. Abu-Safieh L, Alrashed M, Anazi S, Alkuraya H, Khan AO, Al-Owain M, AlZahrani J, Al-Abdi L, Hashem M, Al-Tarimi S, Sebai MA, Shamia A, Ray-Zack MD, Nassan M, Al-Hassnan ZN, Rahbeeni Z, Waheeb S, Alkharashi A, Abboud E, Al-Hazzaa SA, Alkuraya FS: Autozygome-guided exome sequencing in retinal dystrophy patients reveals pathogenetic mutations and novel candidate disease genes. Genome Res 2013, 23:236-247.
31. Davidson AE, Schwarz N, Zelinger L, Stern-Schneider G, Shoemark A, Spitzbarth B, Gross M, Laxer U, Sosna J, Sergouniotis PI, Waseem NH, Wilson R, Kahn RA, Plagnol V, Wolfrum U, Banin E, Hardcastle AJ, Cheetham ME, Sharon D, Webster AR: Mutations in ARL2BP, encoding ADP-ribosylation-factor-like 2 binding protein, cause autosomal-recessive retinitis pigmentosa. Am J Hum Genet 2013: . doi: 10.1016/j.ajhg.2013.06.003.

32. Perrault I, Hanein S, Zanlonghi X, Serre V, Nicouleau M, Defoort-Delhemmes S, Delphin N, Fares-Taie L, Gerber S, Xerri O, Edelson C, Goldenberg A, Duncombe A, Le Meur G, Hamel C, Silva E, Nitschke P, Calvas P, Munnich A, Roche O, Dollfus H, Kaplan J, Rozet JM: Mutations in NMNAT1 cause Leber congenital amaurosis with early-onset severe macular and optic atrophy. Nat Genet 2012, 44:975-977.

33. Koenekoop RK, Wang H, Majewski J, Wang X, Lopez I, Ren H, Chen Y, Li Y, Fishman GA, Genead M, Schwartzentruber J, Solanki N, Traboulsi El, Cheng J, Logan CV, McKibbin M, Hayward BE, Parry DA, Johnson CA, Nageeb M, Finding of Rare Disease Genes (FORGE) Canada Consortium, Poulter JA, Mohamed MD, Jafri H, Rashid Y, Taylor GR, Keser V, Mardon G, Xu H, Inglehearn CF, et al: Mutations in NMNAT1 cause Leber congenital amaurosis and identify a new disease pathway for retinal degeneration. Nat Genet 2012, 44:1035-1039.

34. Falk MJ, Zhang Q, Nakamaru-Ogiso E, Kannabiran C, Fonseca-Kelly Z, Chakarova C, Audo I, Mackay DS, Zeitz C, Borman AD, Staniszewska M, Shukla R, Palavalli L, Mohand-Said S, Waseem NH, Jalali S, Perin JC, Place E, Ostrovsky J, Xiao R, Bhattacharya SS, Consugar M, Webster AR, Sahel JA, Moore AT, Berson EL, Liu Q, Gai X, Pierce EA: NMNAT1 mutations cause Leber congenital amaurosis. Nat Genet 2012, 44:1040-1045.

35. Chiang PW, Wang J, Chen Y, Fu Q, Zhong J, Chen Y, Yi X, Wu R, Gan H, Shi Y, Chen Y, Barnett C, Wheaton D, Day M, Sutherland J, Heon E, Weleber RG, Gabriel LA, Cong P, Chuang K, Ye S, Sallum JM, Qi M: Exome sequencing identifies NMNAT1 mutations as a cause of Leber congenital amaurosis. Nat Genet 2012, 44:972-974.

36. Sergouniotis PI, Davidson AE, Mackay DS, Li Z, Yang X, Plagnol V, Moore AT, Webster AR: Recessive mutations in KCNJ13, encoding an inwardly rectifying potassium channel subunit, cause leber congenital amaurosis. Am J Hum Genet 2011, 89:183-190.

37. Zeitz C, Jacobson SG, Hamel CP, Bujakowska K, Neuillé M, Orhan E, Zanlonghi X, Lancelot ME, Michiels C, Schwartz SB, Bocquet B, Congenital Stationary Night Blindness Consortium, Antonio A, Audier C, Letexier M, Saraiva JP, Luu TD, Sennlaub F, Nguyen H, Poch O, Dollfus H, Lecompte O, Kohl S, Sahel JA, Bhattacharya SS, Audo I: Whole-exome sequencing identifies LRIT3 mutations as a cause of autosomal-recessive complete congenital stationary night blindness. Am J Hum Genet 2013, 92:67-75.

38. Audo I, Bujakowska K, Orhan E, Poloschek CM, Defoort-Dhellemmes S, Drumare I, Kohl S, Luu TD, Lecompte O, Zrenner E, Lancelot ME, Antonio A, Germain A, Michiels C, Audier C, Letexier M, Saraiva JP, Leroy BP, Munier FL, Mohand-Saïd S, Lorenz B, Friedburg C, Preising M, Kellner U, Renner AB, Moskova-Doumanova V, Berger W, Wissinger B, Hamel CP, Schorderet DF, et al: Whole-exome sequencing identifies mutations in GPR179 leading to autosomal-recessive complete congenital stationary night blindness. Am J Hum Genet 2012, 90:321-330.

39. Bredrup C, Saunier S, Oud MM, Fiskerstrand T, Hoischen A, Brackman D, Leh SM, Midtbø M, Filhol E, Bole-Feysot C, Nitschké P, Gilissen C, Haugen OH, Sanders JS, Stolte-Dijkstra I, Mans DA, Steenbergen EJ, Hamel BC, Matignon M, Pfundt R, Jeanpierre C, Boman H, Rødahl E, Veltman JA, Knappskog PM, Knoers NV Roepman $\mathrm{R}$, Arts $\mathrm{HH}$ : Ciliopathies with skeletal anomalies and renal insufficiency due to mutations in the IFT-A gene WDR19. Am J Hum Genet 2011, 89:634-643.

40. Shi Y, Li Y, Zhang D, Zhang H, Li Y, Lu F, Liu X, He F, Gong B, Cai L, Li R, Liao S, Ma S, Lin H, Cheng J, Zheng H, Shan Y, Chen B, Hu J, Jin X, Zhao P, Chen $Y$, Zhang $Y$, Lin $Y$, Li X, Fan Y, Yang H, Wang J, Yang Z: Exome sequencing identifies ZNF644 mutations in high myopia. PLOS Genet 2011, 7:e1002084.

41. Marion V, Stutzmann F, Gérard M, De Melo C, Schaefer E, Claussmann A, Hellé S, Delague V, Souied E, Barrey C, Verloes A, Stoetzel C, Dollfus H: Exome sequencing identifies mutations in LZTFL1, a BBSome and smoothened trafficking regulator, in a family with Bardet-Biedl syndrome with situs inversus and insertional polydactyly. J Med Genet 2012, 49:317-321.

42. Chaki M, Airik R, Ghosh AK, Giles RH, Chen R, Slaats GG, Wang H, Hurd TW, Zhou W, Cluckey A, Gee HY, Ramaswami G, Hong CJ, Hamilton BA, Cervenka I, Ganji RS, Bryja V, Arts HH, van Reeuwijk J, Oud MM, Letteboer SJ, Roepman R, Husson H, Ibraghimov-Beskrovnaya O, Yasunaga T, Walz G, Eley L, Sayer JA, Schermer B, Liebau MC, et al: Exome capture reveals ZNF423 and CEP164 mutations, linking renal ciliopathies to DNA damage response signaling. Cell 2012, 150:533-548. 
43. Puffenberger EG, Jinks RN, Sougnez C, Cibulskis K, Willert RA, Achilly NP, Cassidy RP, Fiorentini C, Heiken KF, Lawrence JJ, Mahoney MH, Miller C, Nair DT, Politi KA, Worcester KN, Setton RA, Dipiazza R, Sherman EA, Eastman JT, Francklyn C, Robey-Bond S, Rider NL, Gabriel S, Morton DH, Strauss KA: Genetic mapping and exome sequencing identify variants associated with five novel diseases. PLoS One 2012, 7:228936.

44. Sergouniotis PI, Davidson AE, Mackay DS, Lenassi E, Li Z, Robson AG, Yang X, Kam $J$, Isaacs TW, Holder GE, Jeffery G, Beck JA, Moore AT, Plagnol V, Webster AR: Biallelic mutations in PLA2G5, encoding group V phospholipase A2, cause benign fleck retina. Am J Hum Genet 2011, 89:782-791.

45. Roosing S, Rohrschneider K, Beryozkin A, Sharon D, Weisschuh N, Staller J, Kohl S, Zelinger L, Peters TA, Neveling K, Strom TM, European Retinal Disease Consortium, van den Born LI, Hoyng CB, Klaver CC, Roepman R, Wissinger B, Banin E, Cremers FP, den Hollander Al: Mutations in RAB28, encoding a farnesylated small GTPase, are associated with autosomal-recessive cone-rod dystrophy. Am J Hum Genet 2013, 93:110-117.

46. Aldahmesh MA, Khan AO, Mohamed JY, Alkuraya H, Ahmed H, Bobis S, Al-Mesfer S, Alkuraya FS: Identification of ADAMTS18 as a gene mutated in Knobloch syndrome. J Med Genet 2011, 48:597-601.

47. Peluso I, Conte I, Testa F, Dharmalingam G, Pizzo M, Collin RW, Meola N, Barbato S, Mutarelli M, Ziviello C, Barbarulo AM, Nigro V, Melone MA, European Retinal Disease Consortium, Simonelli F, Banfi S: The ADAMTS18 gene is responsible for autosomal recessive early onset severe retinal dystrophy. Orphanet I Rare Dis 2013, 8:16.

48. Estrada-Cuzcano A, Neveling K, Kohl S, Banin E, Rotenstreich Y, Sharon D, FalikZaccai TC, Hipp S, Roepman R, Wissinger B, Letteboer SJ, Mans DA, Blokland EA, Kwint MP, Gijsen SJ, van Huet RA, Collin RW, Scheffer H, Veltman JA, Zrenner E, European Retinal Disease Consortium, den Hollander Al, Klevering BJ, Cremers FP: Mutations in C8orf37, encoding a ciliary protein, are associated with autosomal-recessive retinal dystrophies with early macular involvement. Am J Hum Genet 2012, 90:102-109.

49. Raychaudhuri S, lartchouk O, Chin K, Tan PL, Tai AK, Ripke S, Gowrisankar S, Vemuri S, Montgomery K, Yu Y, Reynolds R, Zack DJ, Campochiaro B, Campochiaro P, Katsanis N, Daly MJ, Seddon JM: A rare penetrant mutation in CFH confers high risk of age-related macular degeneration. Nat Genet 2011, 43:1232-1236.

50. van de Ven JP, Nilsson SC, Tan PL, Buitendijk GH, Ristau T, Mohlin FC, Nabuurs SB, Schoenmaker-Koller FE, Smailhodzic D, Campochiaro PA, Zack DJ, Duwari MR, Bakker B, Paun CC, Boon CJ, Uitterlinden AG, Liakopoulos S, Klevering BJ, Fauser S, Daha MR, Katsanis N, Klaver CC, Blom AM, Hoyng CB, den Hollander Al: A functional variant in the CFI gene confers a high risk of age-related macular degeneration. Nat Genet 2013, 45:813-817.

51. Eisenberger T, Slim R, Mansour A, Nauck M, Nurnberg G, Nurnberg P, Decker $C$, Dafinger C, Ebermann I, Bergmann C, Bolz HJ: Targeted next-generation sequencing identifies a homozygous nonsense mutation in ABHD12, the gene underlying PHARC, in a family clinically diagnosed with Usher syndrome type 3. Orphanet J Rare Dis 2012, 7:59.

52. Peachey NS, Ray TA, Florijn R, Rowe LB, Sjoerdsma T, Contreras-Alcantara S, Baba K, Tosini G, Pozdeyev N, luvone PM, Bojang P Jr, Pearring JN, Simonsz HJ, van Genderen M, Birch DG, Traboulsi El, Dorfman A, Lopez I, Ren H, Goldberg AF, Nishina PM, Lachapelle P, McCall MA, Koenekoop RK, Bergen AA, Kamermans M, Gregg RG: GPR179 is required for depolarizing bipolar cell function and is mutated in autosomal-recessive complete congenital stationary night blindness. Am J Hum Genet 2012, 90:331-339.

53. Webb TR, Parfitt DA, Gardner JC, Martinez A, Bevilacqua D, Davidson AE, Zito I, Thiselton DL, Ressa JH, Apergi M, Schwarz N, Kanuga N, Michaelides M, Cheetham $M E$, Gorin MB, Hardcastle AJ: Deep intronic mutation in OFD1, identified by targeted genomic next-generation sequencing, causes a severe form of $X$ linked retinitis pigmentosa (RP23). Hum Mol Genet 2012, 21:3647-3654.

54. Huang L, Szymanska K, Jensen VL, Janecke AR, Innes AM, Davis EE, Frosk P, Li C, Willer JR, Chodirker BN, Greenberg CR, McLeod DR, Bernier FP, Chudley AE, Müller T, Shboul M, Logan CV, Loucks CM, Beaulieu CL, Bowie RV, Bell SM, Adkins J, Zuniga Fl, Ross KD, Wang J, Ban MR, Becker C, Nürnberg P, Douglas S, Craft CM, et al: TMEM237 is mutated in individuals with a Joubert syndrome related disorder and expands the role of the TMEM family at the ciliary transition zone. Am J Hum Genet 2011, 89:713-730.

55. Nikopoulos K, Gilissen C, Hoischen A, van Nouhuys CE, Boonstra FN, Blokland EA, Arts P, Wieskamp N, Strom TM, Ayuso C, Tilanus MA, Bouwhuis S, Mukhopadhyay A, Scheffer H, Hoefsloot LH, Veltman JA, Cremers FP, Collin RW: Next-generation sequencing of a $40 \mathrm{Mb}$ linkage interval reveals TSPAN12 mutations in patients with familial exudative vitreoretinopathy. Am J Hum Genet 2010, 86:240-247.
56. Otto EA, Hurd TW, Airik R, Chaki M, Zhou W, Stoetzel C, Patil SB, Levy S, Ghosh AK, Murga-Zamalloa CA, van Reeuwijk J, Letteboer SJ, Sang L, Giles RH, Liu Q, Coene KL, Estrada-Cuzcano A, Collin RW, McLaughlin HM, Held S, Kasanuki JM, Ramaswami G, Conte J, Lopez I, Washburn J, Macdonald J, Hu J, Yamashita Y, Maher ER, Guay-Woodford LM, et al: Candidate exome capture identifies mutation of SDCCAG8 as the cause of a retinal-renal ciliopathy. Nat Genet 2010, 42:840-850.

57. Ozgul RK, Siemiatkowska AM, Yucel D, Myers CA, Collin RW, Zonneveld MN, Beryozkin A, Banin E, Hoyng CB, van den Born LI, European Retinal Disease Consortium, Bose R, Shen W, Sharon D, Cremers FP, Klevering BJ, den Hollander $\mathrm{Al}$, Corbo JC: Exome sequencing and cis-regulatory mapping identify mutations in MAK, a gene encoding a regulator of ciliary length, as a cause of retinitis pigmentosa. Am J Hum Genet 2011, 89:253-264.

58. Lee JE, Gleeson JG: A systems-biology approach to understanding the ciliopathy disorders. Genome Med 2011, 3:59.

59. Audo I, Mohand-Said S, Dhaenens CM, Germain A, Orhan E, Antonio A, Hamel C, Sahel JA, Bhattacharya SS, Zeitz C: RP1 and autosomal dominant rod-cone dystrophy: novel mutations, a review of published variants, and genotypephenotype correlation. Hum Mutat 2012, 33:73-80.

60. Edwards AO: Clinical features of the congenital vitreoretinopathies. Eye (Lond) 2008, 22:1233-1242.

61. Wang Z, Gerstein M, Snyder M: RNA-Seq: a revolutionary tool for transcriptomics. Nat Rev Genet 2009, 10:57-63.

62. Morozova O, Hirst M, Marra MA: Applications of new sequencing technologies for transcriptome analysis. Annu Rev Genomics Hum Genet 2009, 10:135-151.

63. Wang ET, Sandberg R, Luo S, Khrebtukova I, Zhang L, Mayr C, Kingsmore SF, Schroth GP, Burge CB: Alternative isoform regulation in human tissue transcriptomes. Nature 2008, 456:470-476.

64. Licatalosi DD, Darnell RB: RNA processing and its regulation: global insights into biological networks. Nat Rev Genet 2010, 11:75-87.

65. Wang GS, Cooper TA: Splicing in disease: disruption of the splicing code and the decoding machinery. Nat Rev Genet 2007, 8:749-761.

66. Kirschner R, Rosenberg T, Schultz-Heienbrok R, Lenzner S, Feil S, Roepman R, Cremers FP, Ropers HH, Berger W: RPGR transcription studies in mouse and human tissues reveal a retina-specific isoform that is disrupted in a patient with X-linked retinitis pigmentosa. Hum Mol Genet 1999, 8:1571-1578.

67. Pretorius PR, Baye LM, Nishimura DY, Searby CC, Bugge K, Yang B, Mullins RF, Stone EM, Sheffield VC, Slusarski DC: Identification and functional analysis of the vision-specific BBS3 (ARL6) long isoform. PLoS Genet 2010, 6:e1000884.

68. Mordes D, Luo X, Kar A, Kuo D, Xu L, Fushimi K, Yu G, Sternberg P Jr, Wu JY: Pre-mRNA splicing and retinitis pigmentosa. Mol Vis 2006, 12:1259-1271.

69. Mercer TR, Gerhardt DJ, Dinger ME, Crawford J, Trapnell C, Jeddeloh JA, Mattick JS, Rinn JL: Targeted RNA sequencing reveals the deep complexity of the human transcriptome. Nat Biotechnol 2012, 30:99-104.

70. Deo M, Yu JY, Chung KH, Tippens M, Turner DL: Detection of mammalian microRNA expression by in situ hybridization with RNA oligonucleotides. Dev Dyn 2006, 235:2538-2548.

71. Xu S, Witmer PD, Lumayag S, Kovacs B, Valle D: MicroRNA (miRNA) transcriptome of mouse retina and identification of a sensory organspecific miRNA cluster. J Biol Chem 2007, 282:25053-25066.

72. Wang FE, Zhang C, Maminishkis A, Dong L, Zhi C, Li R, Zhao J, Majerciak V, Gaur AB, Chen S, Miller SS: MicroRNA-204/211 alters epithelial physiology. FASEB J 2010, 24:1552-1571

73. Alfano G, Vitiello C, Caccioppoli C, Caramico T, Carola A, Szego MJ, Mclnnes RR, Auricchio A, Banfi S: Natural antisense transcripts associated with genes involved in eye development. Hum Mol Genet 2005, 14:913-923.

74. Young TL, Matsuda T, Cepko CL: The noncoding RNA taurine upregulated gene 1 is required for differentiation of the murine retina. Curr Biol 2005, 15:501-512.

75. Rapicavoli NA, Poth EM, Zhu H, Blackshaw S: The long noncoding RNA Six3OS acts in trans to regulate retinal development by modulating Six3 activity. Neural Dev 2011, 6:32.

76. Damiani D, Alexander JJ, O'Rourke JR, McManus M, Jadhav AP, Cepko CL, Hauswirth WW, Harfe BD, Strettoi E: Dicer inactivation leads to progressive functional and structural degeneration of the mouse retina. J Neurosci 2008, 28:4878-4887.

77. Kaneko H, Dridi S, Tarallo V, Gelfand BD, Fowler BJ, Cho WG, Kleinman ME, Ponicsan SL, Hauswirth WW, Chiodo VA, Karikó K, Yoo JW, Lee DK, Hadziahmetovic M, Song Y, Misra S, Chaudhuri G, Buaas FW, Braun RE, Hinton DR, Zhang Q, Grossniklaus HE, Provis JM, Madigan MC, Milam AH, Justice NL, 
Albuquerque RJ, Blandford AD, Bogdanovich S, Hirano Y, et al: DICER1 deficit induces Alu RNA toxicity in age-related macular degeneration. Nature 2011, 471:325-330

78. Wittkopp PJ, Kalay G: Cis-regulatory elements: molecular mechanisms and evolutionary processes underlying divergence. Nat Rev Genet 2012, 13:59-69.

79. Corbo JC, Lawrence KA, Karlstetter M, Myers CA, Abdelaziz M, Dirkes W, Weigelt K, Seifert M, Benes V, Fritsche LG, Weber BH, Langmann T: CRX ChIP-seq reveals the cis-regulatory architecture of mouse photoreceptors. Genome Res 2010, 20:1512-1525.

80. Hao H, Kim DS, Klocke B, Johnson KR, Cui K, Gotoh N, Zang C, Gregorski J, Gieser L, Peng W, Fann Y, Seifert M, Zhao K, Swaroop A: Transcriptional regulation of rod photoreceptor homeostasis revealed by in vivo NRL targetome analysis. PLoS Genet 2012, 8:e1002649.

81. Schones DE, Zhao K: Genome-wide approaches to studying chromatin modifications. Nat Rev Genet 2008, 9:179-191.

82. Davis DM, Dyer MA: Retinal progenitor cells, differentiation, and barriers to cell cycle reentry. Curr Top Dev Biol 2010, 93:175-188.

83. Merbs SL, Khan MA, Hackler L Jr, Oliver VF, Wan J, Qian J, Zack DJ: Cellspecific DNA methylation patterns of retina-specific genes. PLoS One 2012, 7:e32602.

84. Hunter A, Spechler PA, Cwanger A, Song Y, Zhang Z, Ying GS, Hunter AK, Dezoeten E, Dunaief JL: DNA methylation is associated with altered gene expression in AMD. Invest Ophthalmol Vis Sci 2012, 53:2089-2105.

85. ENCODE Project Consortium, Bernstein BE, Birney E, Dunham I, Green ED, Gunter C, Snyder M: An integrated encyclopedia of DNA elements in the human genome. Nature 2012, 489:57-74.

86. National Human Genome Research Institute Catalog of Published Genome-Wide Association Studies. [http://www.genome.gov/gwastudies]

87. Klein RJ, Zeiss C, Chew EY, Tsai JY, Sackler RS, Haynes C, Henning AK, SanGiovanni JP, Mane SM, Mayne ST, Bracken MB, Ferris FL, Ott J, Barnstable C, Hoh J: Complement factor $\mathrm{H}$ polymorphism in age-related macular degeneration. Science 2005, 308:385-389.

88. Chen W, Stambolian D, Edwards AO, Branham KE, Othman M, Jakobsdottir J, Tosakulwong N, Pericak-Vance MA, Campochiaro PA, Klein ML, Tan PL, Conley YP, Kanda A, Kopplin L, Li Y, Augustaitis KJ, Karoukis AJ, Scott WK, Agarwal A, Kovach JL, Schwartz SG, Postel EA, Brooks M, Baratz KH, Brown WL, Complications of Age-Related Macular Degeneration Prevention Trial Research Group, Brucker AJ, Orlin A, Brown G, Ho A, et al: Genetic variants near TIMP3 and high-density lipoprotein-associated loci influence susceptibility to age-related macular degeneration. Proc Natl Acad Sci U S A 2010, 107:7401-7406.

89. Manolio TA, Collins FS, Cox NJ, Goldstein DB, Hindorff LA, Hunter DJ, McCarthy MI, Ramos EM, Cardon LR, Chakravarti A, Cho JH, Guttmacher $A E$, Kong A, Kruglyak L, Mardis E, Rotimi CN, Slatkin M, Valle $D$, Whittemore AS, Boehnke M, Clark AG, Eichler EE, Gibson G, Haines JL, Mackay TF, McCarroll SA, Visscher PM: Finding the missing heritability of complex diseases. Nature 2009, 461:747-753.

90. Gibson G: Rare and common variants: twenty arguments. Nat Rev Genet 2011, 13:135-145.

91. Do R, Kathiresan S, Abecasis GR: Exome sequencing and complex disease: practical aspects of rare variant association studies. Hum Mol Genet 2012 , 21:R1-R9.

92. Kiezun A, Garimella K, Do R, Stitziel NO, Neale BM, McLaren PJ, Gupta N, Sklar P, Sullivan PF, Moran JL, Hultman CM, Lichtenstein P, Magnusson P, Lehner T, Shugart YY, Price AL, de Bakker PI, Purcell SM, Sunyaev SR: Exome sequencing and the genetic basis of complex traits. Nat Genet 2012, 44:623-630

93. DeAngelis MM, Lane AM, Shah CP, Ott J, Dryja TP, Miller JW: Extremely discordant sib-pair study design to determine risk factors for neovascular age-related macular degeneration. Arch Ophthalmol 2004, 122:575-580

94. Weber BH, Vogt G, Pruett RC, Stohr H, Felbor U: Mutations in the tissue inhibitor of metalloproteinases-3 (TIMP3) in patients with Sorsby's fundus dystrophy. Nat Genet 1994, 8:352-356.

95. Allikmets R, Singh N, Sun H, Shroyer NF, Hutchinson A, Chidambaram A, Gerrard B, Baird L, Stauffer D, Peiffer A, Rattner A, Smallwood P, Li Y, Anderson KL, Lewis RA, Nathans J, Leppert M, Dean M, Lupski JR: A photoreceptor cell-specific ATPbinding transporter gene $(A B C R)$ is mutated in recessive Stargardt macular dystrophy. Nat Genet 1997, 15:236-246.

96. Allikmets R: Further evidence for an association of $A B C R$ alleles with age-related macular degeneration. The International ABCR Screening Consortium. Am J Hum Genet 2000, 67:487-491.
97. Girirajan S, Campbell CD, Eichler EE: Human copy number variation and complex genetic disease. Annu Rev Genet 2011, 45:203-226.

98. Liu MM, Chan CC, Tuo J: Genetic mechanisms and age-related macular degeneration: common variants, rare variants, copy number variations, epigenetics, and mitochondrial genetics. Hum Genomics 2012, 6:13.

99. Sivakumaran TA, Igo RP Jr, Kidd JM, Itsara A, Kopplin $\sqcup$, Chen W, Hagstrom SA, Peachey NS, Francis PJ, Klein ML, Chew EY, Ramprasad VL, Tay WT, Mitchell P, Seielstad M, Stambolian DE, Edwards AO, Lee KE, Leontiev DV, Jun G, Wang Y, Tian L, Qiu F, Henning AK, LaFramboise T, Sen P, Aarthi M, George R, Raman R, Das MK, et al: A $32 \mathrm{~kb}$ critical region excluding $\mathrm{Y} 402 \mathrm{H}$ in $\mathrm{CFH}$ mediates risk for age-related macular degeneration. PLoS One 2011, 6:e25598.

100. Meyer KJ, Davis LK, Schindler El, Beck JS, Rudd DS, Grundstad AJ, Scheetz TE, Braun TA, Fingert JH, Alward WL, Kwon YH, Folk JC, Russell SR, Wassink TH, Stone EM, Sheffield VC: Genome-wide analysis of copy number variants in age-related macular degeneration. Hum Genet 2011, 129:91-100.

101. Hageman GS, Hancox LS, Taiber AJ, Gehrs KM, Anderson DH, Johnson LV, Radeke MJ, Kavanagh D, Richards A, Atkinson J, Meri S, Bergeron J, Zernant J, Merriam J, Gold B, Allikmets R, Dean M, AMD Clinical Study Group: Extended haplotypes in the complement factor $\mathrm{H}$ (CFH) and CFH-related (CFHR) family of genes protect against age-related macular degeneration: characterization, ethnic distribution and evolutionary implications. Ann Med 2006, 38:592-604.

102. Hughes AE, Orr N, Esfandiary H, Diaz-Torres M, Goodship T, Chakravarthy U: A common CFH haplotype, with deletion of CFHR1 and CFHR3, is associated with lower risk of age-related macular degeneration. Nat Genet 2006, 38:1173-1177.

103. Spencer KL, Hauser MA, Olson LM, Schmidt S, Scott WK, Gallins P, Agarwal A, Postel EA, Pericak-Vance MA, Haines JL: Deletion of CFHR3 and CFHR1 genes in age-related macular degeneration. Hum Mol Genet 2008, 17:971-977

104. Liu MM, Agron E, Chew E, Meyerle C, Ferris FL 3rd, Chan CC, Tuo J: Copy number variations in candidate genes in neovascular age-related macular degeneration. Invest Ophthalmol Vis Sci 2011, 52:3129-3135.

105. Korbel JO, Urban AE, Affourtit JP, Godwin B, Grubert F, Simons JF, Kim PM, Palejev D, Carriero NJ, Du L, Taillon BE, Chen Z, Tanzer A, Saunders AC, Chi J, Yang F, Carter NP, Hurles ME, Weissman SM, Harkins TT, Gerstein MB, Egholm M, Snyder M: Paired-end mapping reveals extensive structural variation in the human genome. Science 2007, 318:420-426.

106. Tuzun E, Sharp AJ, Bailey JA, Kaul R, Morrison VA, Pertz LM, Haugen E, Hayden H, Albertson D, Pinkel D, Olson MV, Eichler EE: Fine-scale structural variation of the human genome. Nat Genet 2005, 37:727-732.

107. Alkan C, Coe BP, Eichler EE: Genome structural variation discovery and genotyping. Nat Rev Genet 2011, 12:363-376.

108. Bodmer W, Bonilla C: Common and rare variants in multifactorial susceptibility to common diseases. Nat Genet 2008, 40:695-701.

109. Pritchard JK: Are rare variants responsible for susceptibility to complex diseases? Am J Hum Genet 2001, 69:124-137.

110. 1000 Genomes Project Consortium, Abecasis GR, Auton A, Brooks LD, DePristo MA, Durbin RM, Handsaker RE, Kang HM, Marth GT, McVean GA An integrated map of genetic variation from 1,092 human genomes. Nature 2012, 491:56-65.

111. Fu W, O'Connor TD, Jun G, Kang HM, Abecasis G, Leal SM, Gabriel S, Rieder MJ, Altshuler D, Shendure J, Nickerson DA, Bamshad MJ, NHLBI Exome Sequencing Project, Akey JM: Analysis of 6,515 exomes reveals the recent origin of most human protein-coding variants. Nature 2013, 493:216-220.

112. Exome Chip Design. [http://genome.sph.umich.edu/wiki/ Exome_Chip_Design].

113. Cheung VG, Spielman RS, Ewens KG, Weber TM, Morley M, Burdick JT: Mapping determinants of human gene expression by regional and genome-wide association. Nature 2005, 437:1365-1369.

114. Majewski J, Pastinen T: The study of eQTL variations by RNA-seq: from SNPs to phenotypes. Trends Genet 2011, 27:72-79.

115. Cooper GM, Shendure J: Needles in stacks of needles: finding disease-causal variants in a wealth of genomic data. Nat Rev Genet 2011, 12:628-640.

116. Branham K, Othman M, Brumm M, Karoukis AJ, Atmaca-Sonmez P, Yashar BM, Schwartz SB, Stover NB, Trzupek K, Wheaton D, Jennings B, Ciccarelli ML, Jayasundera KT, Lewis RA, Birch D, Bennett J, Sieving PA, Andreasson S, Duncan JL, Fishman GA, lannaccone A, Weleber RG, Jacobson SG, Heckenlively JR, Swaroop A: Mutations in RPGR and RP2 account for $15 \%$ of males with simplex retinal degenerative disease. Invest Ophthalmol Vis Sci 2012, 53:8232-8237. 
117. Churchill JD, Bowne SJ, Sullivan LS, Lewis RA, Wheaton DK, Birch DG, Branham KE, Heckenlively JR, Daiger SP: Mutations in the X-linked retinitis pigmentosa genes RPGR and RP2 found in $8.5 \%$ of families with a provisional diagnosis of autosomal dominant retinitis pigmentosa. Invest Ophthalmol Vis Sci 2013, 54:1411-1416.

118. Swaroop A: What's in a name? RPGR mutations redefine the genetic and phenotypic landscape in retinal degenerative diseases. Invest Ophthalmol Vis Sci 2013, 54:1417.

119. Bowne SJ, Sullivan LS, Koboldt DC, Ding L, Fulton R, Abbott RM, Sodergren EJ, Birch DG, Wheaton DH, Heckenlively JR, Liu Q, Pierce EA, Weinstock GM, Daiger SP: Identification of disease-causing mutations in autosomal dominant retinitis pigmentosa (adRP) using next-generation DNA sequencing. Invest Ophthalmol Vis Sci 2011, 52:494-503.

120. Neveling K, Collin RW, Gilissen C, van Huet RA, Visser L, Kwint MP, Gijsen SJ, Zonneveld MN, Wieskamp N, de Ligt J, Siemiatkowska AM, Hoefsloot LH, Buckley MF, Kellner U, Branham KE, den Hollander Al, Hoischen A, Hoyng C, Klevering BJ, van den Born LI, Veltman JA, Cremers FP, Scheffer H: Next-generation genetic testing for retinitis pigmentosa. Hum Mutat 2012, 33:963-972.

121. Booij JC, Bakker A, Kulumbetova J, Moutaoukil Y, Smeets B, Verheij J, Kroes HY, Klaver CC, van Schooneveld M, Bergen AA, Florijn RJ: Simultaneous mutation detection in 90 retinal disease genes in multiple patients using a custom-designed 300-kb retinal resequencing chip. Ophthalmology 2011, 118:160-167. e1-3.

122. Song J, Smaoui N, Ayyagari R, Stiles D, Benhamed S, MacDonald IM, Daiger SP, Tumminia SJ, Hejtmancik F, Wang X: High-throughput retina-array for screening 93 genes involved in inherited retinal dystrophy. Invest Ophthalmol Vis Sci 2011, 52:9053-9060.

123. Blain $\mathrm{D}$, Goetz KE, Ayyagari R, Tumminia SJ: eyeGENE(R): a vision community resource facilitating patient care and paving the path for research through molecular diagnostic testing. Clin Genet 2013, 84:190-197.

124. Haider NB, Ikeda A, Naggert JK, Nishina PM: Genetic modifiers of vision and hearing. Hum Mol Genet 2002, 11:1195-1206.

125. Nadeau JH: Modifier genes in mice and humans. Nat Rev Genet 2001, 2:165-174

126. Kajiwara K, Berson EL, Dryja TP: Digenic retinitis pigmentosa due to mutations at the unlinked peripherin/RDS and ROM1 loci. Science 1994, 264:1604-1608.

127. Poloschek CM, Bach M, Lagreze WA, Glaus E, Lemke JR, Berger W, Neidhardt J: ABCA4 and ROM1: implications for modification of the PRPH2associated macular dystrophy phenotype. Invest Ophthalmol Vis Sci 2010, 51:4253-4265

128. Venturini G, Rose AM, Shah AZ, Bhattacharya SS, Rivolta C: CNOT3 is a modifier of PRPF31 mutations in retinitis pigmentosa with incomplete penetrance. PLoS Genet 2012, 8:e1003040.

129. Wiszniewski W, Lewis RA, Stockton DW, Peng J, Mardon G, Chen R, Lupski JR: Potential involvement of more than one locus in trait manifestation for individuals with Leber congenital amaurosis. Hum Genet 2011, 129:319-327.

130. Hildebrandt F, Benzing T, Katsanis N: Ciliopathies. N Engl J Med 2011, 364:1533-1543.

131. Rachel RA, Li T, Swaroop A: Photoreceptor sensory cilia and ciliopathies: focus on CEP290, RPGR and their interacting proteins. Cilia 2012, 1:22.

132. Khanna H, Davis EE, Murga-Zamalloa CA, Estrada-Cuzcano A, Lopez I, den Hollander Al, Zonneveld MN, Othman MI, Waseem N, Chakarova CF, Maubaret C, Diaz-Font A, MacDonald I, Muzny DM, Wheeler DA, Morgan M, Lewis LR, Logan CV, Tan PL, Beer MA, Inglehearn CF, Lewis RA, Jacobson SG, Bergmann C, Beales PL, Attié-Bitach T, Johnson CA, Otto EA, Bhattacharya SS, Hildebrandt F, et al: A common allele in RPGRIP1L is a modifier of retinal degeneration in ciliopathies. Nat Genet 2009, 41:739-745.

133. Coppieters F, Casteels I, Meire F, De Jaegere S, Hooghe S, van Regemorter N, Van Esch H, Matuleviciene A, Nunes L, Meersschaut V, Walraedt S, Standaert L, Coucke P, Hoeben H, Kroes HY, Vande Walle J, de Ravel T, Leroy BP, De Baere E: Genetic screening of LCA in Belgium: predominance of CEP290 and identification of potential modifier alleles in AHI1 of CEP290-related phenotypes. Hum Mutat 2010, 31:E1709-E1766.

134. Louie CM, Caridi G, Lopes VS, Brancati F, Kispert A, Lancaster MA, Schlossman AM, Otto EA, Leitges M, Gröne HJ, Lopez I, Gudiseva HV, OToole JF, Vallespin E, Ayyagari R, Ayuso C, Cremers FP, den Hollander Al, Koenekoop RK, Dallapiccola B, Ghiggeri GM, Hildebrandt F, Valente EM, Williams DS, Gleeson JG: AHI1 is required for photoreceptor outer segment development and is a modifier for retinal degeneration in nephronophthisis. Nat Genet 2010, 42:175-180.
135. Ebermann I, Phillips JB, Liebau MC, Koenekoop RK, Schermer B, Lopez I, Schafer E, Roux AF, Dafinger C, Bernd A, Zrenner E, Claustres M, Blanco B, Nürnberg $G$, Nürnberg $P$, Ruland $R$, Westerfield $M$, Benzing $T$, Bolz HJ: PDZD7 is a modifier of retinal disease and a contributor to digenic Usher syndrome. J Clin Invest 2010, 120:1812-1823.

136. Rachel RA, May-Simera HL, Veleri S, Gotoh N, Choi BY, Murga-Zamalloa C, Mclntyre JC, Marek J, Lopez I, Hackett AN, Zhang J, Brooks M, den Hollander Al, Beales PL, Li T, Jacobson SG, Sood R, Martens JR, Liu P, Friedman TB, Khanna H, Koenekoop RK, Kelley MW, Swaroop A: Combining Cep290 and Mkks ciliopathy alleles in mice rescues sensory defects and restores ciliogenesis. J Clin Invest 2012, 122:1233-1245.

\section{doi:10.1186/gm488}

Cite this article as: Ratnapriya and Swaroop: Genetic architecture of retinal and macular degenerative diseases: the promise and challenges of next-generation sequencing. Genome Medicine 2013 5:84. 